\title{
Mineral nutrition of buckwheat in fluoride polluted soil: case study in pot experiment
}

\section{Olga Pavlova1, Andrey Litvinovich ${ }^{1,2}$, Anton Lavrishchev ${ }^{2}$, Vladimir Bure ${ }^{1,3}$, and Elmira Saljnikov ${ }^{4,5}$}

${ }^{1}$ Agrophysical Research Institute, Grazhdanskiy pr., 14, Saint Petersburg, 195220, Russian Federation

2Saint Petersburg State Agrarian University, Peterburgskoye shosse, 2, Saint Petersburg, 196601, Russian Federation

${ }^{3}$ Saint Petersburg State University, Universitetskaya nab., 7-9, Saint Petersburg, 199034, Russian Federation

${ }^{4}$ Soil Science Institute, Teodora Drajzera 7, Belgrade, 11000, Serbia

${ }^{5}$ Mitscherlich Akademie für Bodenfruchtbarkeit (MITAK), GmbH, 14641, Paulinenaue, Prof.-Mitscherlich-Alle 1, Germany

Address correspondence and requests for materials to Anton Lavrishchev, av.lavrishchev@yandex.ru

\section{Abstract}

The research aimed to establish an optimal and safe level of mineral nutrition for buckwheat grown in the fluoride contaminated soil by defining yield and chemical composition of buckwheat grown on acidic soddy-podzolic soil under different levels of fertilization, and assessing the possibility of reducing fluoride phytotoxicity. The mechanisms of plant uptake of fluoride may be influenced by interaction in nutrient uptake by plant. Sodium fluoride solution was applied at the rate of $100 \mathrm{mg}$ per $1 \mathrm{~kg}$ of soil mass. Two different experiments were studied under controlled conditions: the first experiment with increasing doses of ammonium nitrate, and the second experiment with increasing doses of orthophosphoric acid. Increase of $\mathrm{N}$ fertilization resulted in an increase in the concentration of fluoride in the tissues of buckwheat and lowers yields of plants, while application of $\mathrm{P}$ reduced uptake of fluoride and increased productivity of buckwheat. In fluoride contaminated soil the chemical composition of buckwheat was affected by synergism and antagonism of individual elements during absorption by plants. A protective mechanism of buckwheat against negative effect of fluoride was due to its ability to activate metabolism regulating the flow of individual elements in tissue that reduces the adverse impact of pollutant.

Keywords: buckwheat, fertilizer, fluoride, contamination, nitrogen, phosphorus.

\section{Introduction}

Fluoride is a serious environmental pollutant. Fluoride accumulation in the soil occurs as a result of volatile emissions from industrial enterprises (Weinstein and Davison, 2004; Singh et al., 2016) and long-term use of mineral fertilizers and ameliorants (Gautam et al., 2010; Anshumali, 2014).

Possessing high chemical activity, fluoride can have a negative effect on biochemical processes in plants, inhibiting their growth and development (KabataPendias and Pendias, 1989; Stevens, 1996; Elrashidi et al., 1998; Sheudshen, 2003; Gautam et al., 2010; Gupta et al., 2011; Mishra et al., 2014; Hong et al., 2016; Szostek and Ciecko, 2017; Mian et al., 2018).

The most significant effects of fluoride on plant metabolism are manifested in a reduced rate of oxygen uptake, respiratory disorder, reduced nutrient assimilation, reduced chlorophyll content, inhibited starch synthesis, suppressed 
pyrophosphatase function, altered cell organelles metabolism, damaged cell membranes, destruction of DNA and RNA, and the synthesis of fluoroacetate - the most toxic fluoride compound (Kabata-Pendias and Pendias, 1989; Mian et al., 2018).

Plants considered sensitive to the effects of fluoride are damaged at concentrations in vegetative organs from 20 to $150 \mathrm{mg} \mathrm{F} / \mathrm{kg}$ dry weight, while less sensitive plants are able to tolerate up to $200 \mathrm{mg} / \mathrm{kg}$, and very resistant ones do not experience a negative effect when $\mathrm{F}$ is present in tissues in concentrations higher than $500 \mathrm{mg} / \mathrm{kg}$ (Weinstein and Davison, 2004).

A harmless dose of fluoride is different for each plant species and is determined by the individual characteristics of the culture, such as activity of vital processes and growth conditions. Buckwheat is an important culture from the aspect of its nutritive values, and it is becoming increasingly popular, especially among consumers favoring a healthy lifestyle. This crop belongs to the group of plants that are sensitive to an excess of fluoride in the soils. Depending on the growing conditions, the concentration of fluoride in the tissues of buckwheat can vary from 7 to $196 \mathrm{mg} / \mathrm{kg}$ of dry weight of plants (Vlasyuk, 1969).

Despite the large number of studies on fluoride, the effect on the mineral nutrition and the chemical composition of plants grown in F-contaminated soils has not been studied enough, while the mechanisms of interaction of the elements during adsorption of nutrients is not clear. There is no information about the possibility of reducing the phytotoxicity of fluoride by adjusting the dosage and combination of mineral fertilizers.

The goals of this study were to define the yield and chemical composition of buckwheat plants grown on acidic fluoride-contaminated soddy-podzolic soil at different levels of fertilization; to assess the possibility of reducing fluoride phytotoxicity; to identify buckwheat protective mechanisms against negative effects of the pollutant; and to develop empirical models to establish the relationship between the concentration of fluoride in the tissues of the plant and buckwheat yield.

\section{Materials and methods}

Abbreviations: PK - superphosphate and potassium chloride; NK - ammonium nitrate and potassium chloride.

The study was conducted in two pot experiments (Table 1 and 2) on soddy-podzolic sandy loam soil: $\mathrm{pH}$ in $\mathrm{KCl} 4.4$, humus $-2.8 \%$; particles $<0.01 \mathrm{~mm}-$ $13.8 \%$. Sodium fluoride solution was applied at the rate of $100 \mathrm{mg}$ per $1 \mathrm{~kg}$ of soil mass on the soil planted with buckwheat.

In the first experiment (No. 1), ammonium nitrate was applied in increasing doses of 1,2 and $3 \mathrm{~g}$ of $\mathrm{N}$ per pot, which each pot containing $5 \mathrm{~kg}$ of soil. Phosphorus and potassium (PK) were applied in doses of $1 \mathrm{~g}$ each per pot in the form of superphosphate and potassium chloride. As a control treatment in the experiment, only PK was used.

In the second experiment (No. 2), an orthophosphoric acid was used in increasing doses of 1,2 and $3 \mathrm{~g}$ of $\mathrm{P}_{2} \mathrm{O}_{5}$ per pot. Orthophosphoric acid was used to eliminate the possible side effects of calcium, which is part of the superphosphate. Nitrogen-potassium (NK) fertilizer was applied at a rate of $1 \mathrm{~g}$ each per pot in the form of ammonium nitrate and potassium chloride. As a control treatment in the experiment, only NK was used.

Each experiment was conducted in four replications. During the entire period of the experiment, soil moisture was supplied at $60 \%$ of the full field moisture capacity. Each pot contained 15 plants. The duration of both experiments was 1.5 months. Buckwheat plants were harvested in the flowering phase.

The chemical composition of buckwheat was analysed on a TEFA X-ray fluorescence spectrophotometer (ORTEK). Fluoride concentration was determined potentiometrically using a fluoride selective electrode. The analytical results were processed statistically (Bure, 2007).

\section{Results}

\section{Buckwheat yield and chemical composition depending on the degree of contamination by fluoride and on the fertilization scheme}

Addition of fluoride to the soil fertilized with PK fertilizer contributed to the growth of buckwheat productivity. The yield increase was $15 \%$ compared to the control (Fig. 1). This is probably due to several reasons.

In Experiment No. 1 the harmful effect of fluoride on plants was clearly manifested when $\mathrm{N}$ was added to the soil fertilized by PK. The use of ammonium nitrate in a dose of $1 \mathrm{~g}$ of $\mathrm{N}$ resulted in a $15 \%$ decrease in buckwheat yield compared with the control and a $27 \%$ decrease compared with the PK+F treatment (Fig. 1). With further increase in the dose of ammonium nitrate, the decrease in productivity compared to the control was $23 \%$ at $2 \mathrm{~g}$ of $\mathrm{N}$ and $30 \%$ at $3 \mathrm{~g}$ of $\mathrm{N}$, respectively.

The use of ammonium nitrate did not affect soil acidity. After harvesting, the $\mathrm{pH}$ in $\mathrm{KCl}$ remained at the same level $\left(\mathrm{pH}_{\mathrm{KCl}}=4.4\right)$.

In Experiment No. 2 fluoride contamination of the soil fertilized with NK resulted in a decrease in buckwheat yield. Its dry mass compared with all other treatments of both experiments was the least, i.e., $33 \%$ less than in the control (Fig. 2).

The opposite effect was observed when an orthophosphoric acid was added to the soil. Addition of $1 \mathrm{~g}$ of 
Table 1. Chemical composition of buckwheat grown on fluoride contaminated soil when applying increasing doses of nitrogen fertilizers

\begin{tabular}{|c|c|c|c|c|c|c|c|c|c|c|}
\hline & Treatment & $\mathrm{F}$ & $\mathrm{N}$ & $\mathrm{Ca}$ & $\mathrm{Mg}$ & $\mathrm{P}$ & $\mathrm{s}$ & K & $\mathrm{Mn}$ & $\mathrm{Cl}$ \\
\hline & g/pot & $\mathrm{mg} / \mathrm{kg}$ d.w. & \multicolumn{8}{|c|}{$\%$ of plant dry weight } \\
\hline 1 & $\mathrm{PK}^{\dagger}$ & 3.8 & 2.71 & 1.00 & 0.67 & 0.42 & 0.35 & 3.51 & 0.05 & 2.44 \\
\hline 2 & $\mathrm{PK}+\mathrm{F}$ & 28.6 & 3.16 & 0.69 & 0.68 & 0.47 & 0.32 & 3.92 & 0.03 & 2.07 \\
\hline 3 & $\mathrm{PK}+\mathrm{F}+\mathrm{N}(1 \mathrm{~g})$ & 35.3 & 3.53 & 0.88 & 0.46 & 0.40 & 0.22 & 3.95 & 0.20 & 0.56 \\
\hline 4 & $\mathrm{PK}+\mathrm{F}+\mathrm{N}(2 \mathrm{~g})$ & 36.4 & 4.40 & 0.89 & 0.37 & 0.43 & 0.29 & 3.32 & 0.17 & 0.75 \\
\hline \multirow[t]{2}{*}{5} & $\mathrm{PK}+\mathrm{F}+\mathrm{N}(3 \mathrm{~g})$ & 43.3 & 4.46 & 0.93 & 0.34 & 0.42 & 0.28 & 3.16 & 0.17 & 0.72 \\
\hline & LSD $_{05}$ & 3.82 & 0.24 & 0.12 & 0.09 & - & - & - & 0.06 & 0.21 \\
\hline
\end{tabular}

† PK - $1 \mathrm{~g}$ per $5 \mathrm{~kg}$ soil of phosphorus-potassium fertilizers were applied as a superphosphate and potassium chloride; $\mathrm{F}$ was applied in a rate of $100 \mathrm{mg}$ per $1 \mathrm{~kg}$ of soil mass as a sodium fluoride solution; $\mathrm{N}$ - ammonium nitrate was applied in increasing doses of $1 ; 2$ and $3 \mathrm{~g}$ of $\mathrm{N}$ per $5 \mathrm{~kg}$ of soil.

Table 2. Chemical composition of buckwheat grown on fluoride contaminated soil when applying increasing doses of phosphate fertilizers

\begin{tabular}{|c|c|c|c|c|c|c|c|c|c|c|}
\hline & \multirow{2}{*}{$\begin{array}{l}\text { Treatment, } \\
\text { g/pot }\end{array}$} & $\mathrm{F}$ & $\mathrm{N}$ & $\mathrm{Ca}$ & $\mathrm{Mg}$ & $P$ & $\mathrm{~s}$ & K & $\mathrm{Mn}$ & $\mathrm{Cl}$ \\
\hline & & $\mathrm{mg} / \mathrm{kg}$ d.w. & \multicolumn{8}{|c|}{$\%$ of plant dry weight } \\
\hline 1 & NK† & 4.6 & 4.08 & 1.23 & 0.41 & 0.22 & 0.25 & 3.72 & 0.18 & 0.61 \\
\hline 2 & $\mathrm{NK}+\mathrm{F}$ & 51.5 & 3.92 & 1.12 & 0.51 & 0.28 & 0.22 & 3.87 & 0.19 & 0.49 \\
\hline 3 & $\mathrm{NK}+\mathrm{F}+\mathrm{P}_{2} \mathrm{O}_{5}(1 \mathrm{~g})$ & 36.3 & 3.83 & 1.00 & 0.48 & 0.42 & 0.21 & 4.11 & 0.26 & 0.45 \\
\hline 4 & $\mathrm{NK}+\mathrm{F}+\mathrm{P}_{2} \mathrm{O}_{5}(2 \mathrm{~g})$ & 30.4 & 4.20 & 0.80 & 0.46 & 0.60 & 0.17 & 4.24 & 0.24 & 0.54 \\
\hline \multirow[t]{2}{*}{5} & $\mathrm{NK}+\mathrm{F}+\mathrm{P}_{2} \mathrm{O}_{5}(3 \mathrm{~g})$ & 31.6 & 3.89 & 0.76 & 0.47 & 0.79 & 0.23 & 4.07 & 0.22 & 0.58 \\
\hline & LSD 05 & 5.6 & & 0.15 & 0.06 & 0.09 & & 0.19 & 0.04 & \\
\hline
\end{tabular}

† NK - $1 \mathrm{~g}$ per $5 \mathrm{~kg}$ soil of nitrogen-potassium fertilizers were applied as a ammonium nitrate and potassium chloride; $\mathrm{F}$ was applied in a rate of $100 \mathrm{mg}$ per $1 \mathrm{~kg}$ of soil mass as a sodium fluoride solution; $\mathrm{P}$ - orthophosphoric acid was applied in increasing doses of $1 ; 2$ and $3 \mathrm{~g}$ of $\mathrm{P}$ per $5 \mathrm{~kg}$ of soil.

$\mathrm{P}_{2} \mathrm{O}_{5}$ virtually mitigated the harmful effect of fluoride. Buckwheat yield increased and amounted to $95 \%$ compared to the control.

The use of orthophosphoric acid at a dose of $3 \mathrm{~g}$ per pot contributed to a slight acidification. After harvesting, the $\mathrm{pH}$ in $\mathrm{KCl}$ of the soil decreased by 0.1 units to 4.3. The soil remained in the category of strongly acidic. Increased phosphate nutrition on the background of NK fertilizers contributed to further increase buckwheat productivity. The yield of dry mass of plants when using 2 and $3 \mathrm{~g} \mathrm{P}_{2} \mathrm{O}_{5}$ was 153.8 and $190.5 \mathrm{~g} /$ pot, respectively. The yield increase compared to the control was 9 and $28 \%$, respectively. Consequently, the highest productivity of the dry weight of buckwheat was achieved in the treatment fertilized with the maximum dose of phosphorus.

The Mg concentration in buckwheat tissues decreased with an increase in the dose of ammonium nitrate. The correlation coefficient between $\mathrm{F}$ and $\mathrm{Mg}$ was $\mathrm{r}=-0.91$. The significant difference in $\mathrm{Mg}$ content in buckwheat plants grown on fluoride-contaminated soil without nitrogen fertilizers was two times higher than in the treatment with the highest dose of ammonium nitrate.
An increase in Mn uptake in buckwheat tissue was also observed in the treatments with increasing doses of orthophosphoric acid (Exp. No. 2) as compared to the control. However, in this experiment, an increase in the concentration of $\mathrm{Mn}$ in plants was not accompanied by a decrease in the concentration of $\mathrm{Mg}$ in the tissues $(\mathrm{r}=0.28)$.

In the experiment with increasing doses of ammonium nitrate, the content of potassium in buckwheat did not exceed $3.95 \%$, while the range of fluctuations in the concentration of potassium in the tissues of buckwheat in the treatments using orthophosphoric acid was from 4.07 to $4.24 \%$.

In most of the treatments of the first experiment, the total content of $\mathrm{P}$ and $\mathrm{S}$ was less than the content of $\mathrm{Cl}$. In the second experiment, this pattern was established only in the control treatment (correlation coefficient between $\mathrm{P}$ and $\mathrm{S}$ in the first experiment was $\mathrm{r}=0.56$, while in the second experiment it was $r=-0.38$ ).

The increase in fluoride concentration in buckwheat resulted in a significant decrease in the chlorine concentration, both in the experiment with different doses of 


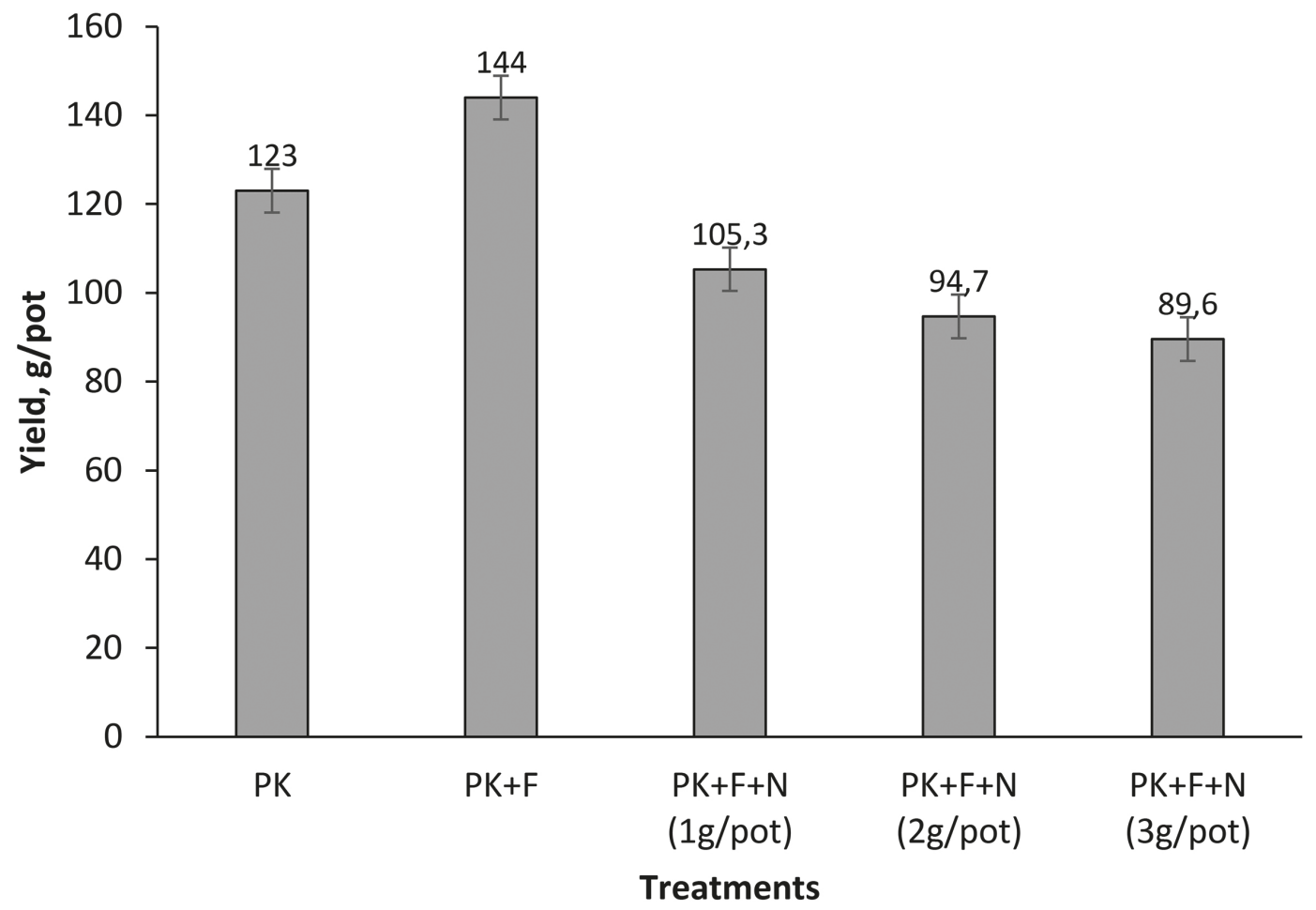

Fig. 1. Yield of buckwheat grown on fluoride-contaminated soil when applying increasing doses of nitrogen fertilizer.

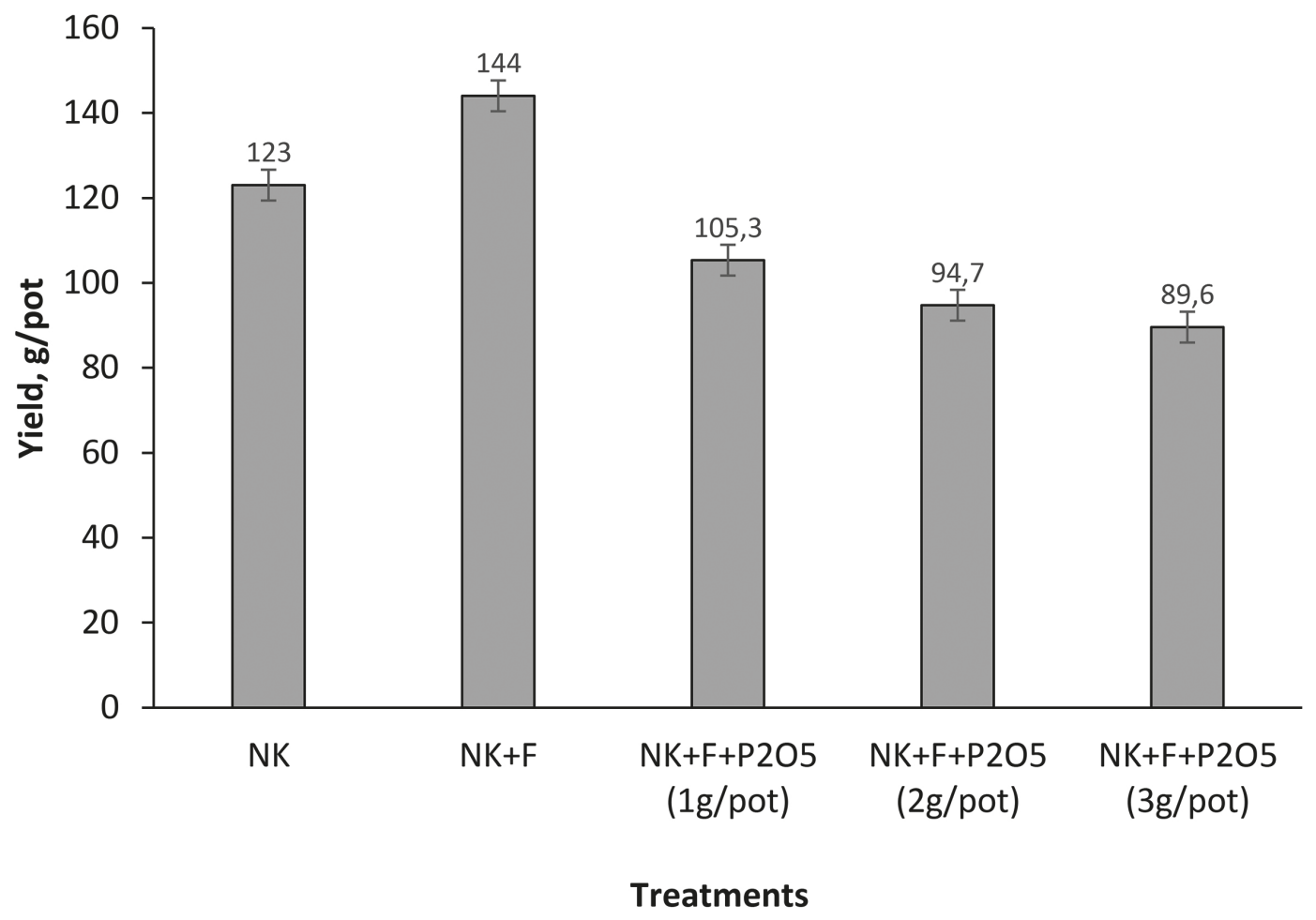

Fig. 2. Yield of buckwheat grown on fluoride-contaminated soil when applying increasing doses of phosphorus fertilizer. 


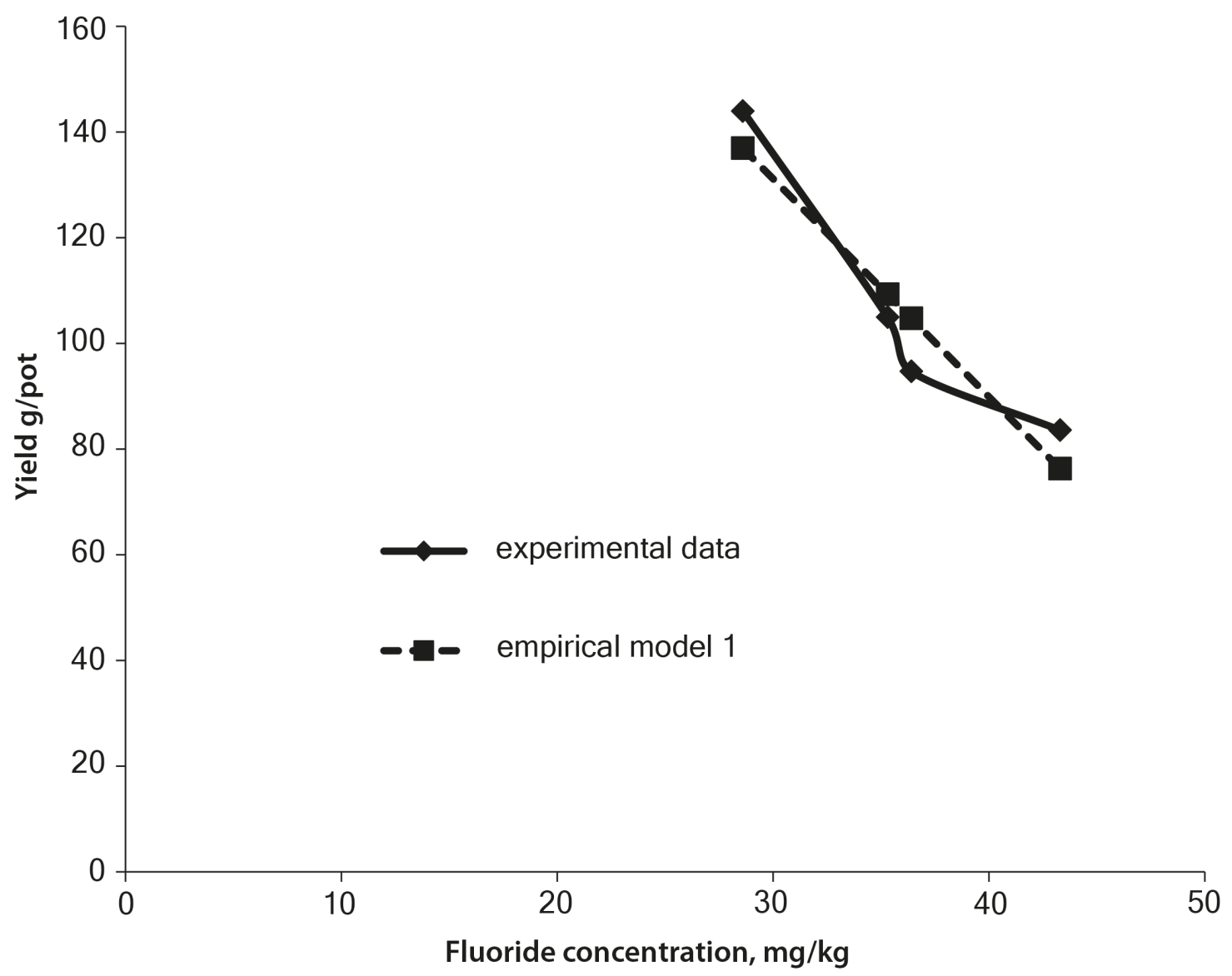

Fig. 3. The dependence of the yield of buckwheat on the concentration of fluoride in plant tissues (experiment with nitrogen fertilizers).

nitrogen fertilizer $(\mathrm{r}=-0.78)$ and in the experiment with increasing doses of phosphate fertilizer $(r=-0.76)$, indicating an antagonism in the assimilation of $\mathrm{F}$ and $\mathrm{Cl}$ by buckwheat plants.

Empirical description of the relationship between the concentration of fluoride in the tissues of buckwheat and its productivity

In building the empirical models, the control treatments were not taken into account.

In Experiment No. 1, a pair-wise linear regression of the yields (indicator $y$ ) on the concentration of fluoride (indicator $x$ ) resulted in the model (1):

$$
y_{1}=254.9-4.1 \cdot x
$$

where $x$ - fluoride concentration. This model is statistically significant at $5.55 \%(\mathrm{~F}=16.58$, critical value $\mathrm{F}(0.9445 ; 1.2)=16.53 ; R^{2}=0.89$, (Fig. 3 ). The coefficient $\mathrm{b}=-4.1$ shows how many units of yield decrease on average over the entire range of fluoride changes in buckwheat tissues with an increase of $\mathrm{F}$ concentration by one unit (within the range of $\mathrm{F}$ concentration changes in tissues from 28.6 to $43.3 \mathrm{mg} / \mathrm{kg}$ ).
In Experiment No. 2, a pair-wise linear regression of the yields (indicator $y$ ) on the concentration of fluoride (indicator $x$ ) resulted in the model (2):

$$
y_{2}=280.4-3.69 \cdot x \text {, }
$$

where $x$ - fluoride concentration. This model is statistically significant at $12.35 \%(\mathrm{~F}=6.65$, critical value $\mathrm{F}(0.8765$; $1.2)=6.63 ; R^{2}=0.768$ (Fig. 4). The coefficient $b=3.69$ shows how many units of yield decrease on average over the entire range of fluorine changes in buckwheat tissues, with an increase in the concentration of $\mathrm{F}$ by one unit (within the range of $\mathrm{F}$ in tissues from 30.4 to $51.5 \mathrm{mg} / \mathrm{kg}$ ).

\section{Discussions}

\section{Buckwheat yield depending on the degree of contamination by fluoride and on the fertilization scheme}

It is known that sodium fluoride has multiple effects on soil (Stevens, 1996). For example, Ilkun et al. (1978) reported that its addition to acidic soil at a dose of $100 \mathrm{mg} /$ 


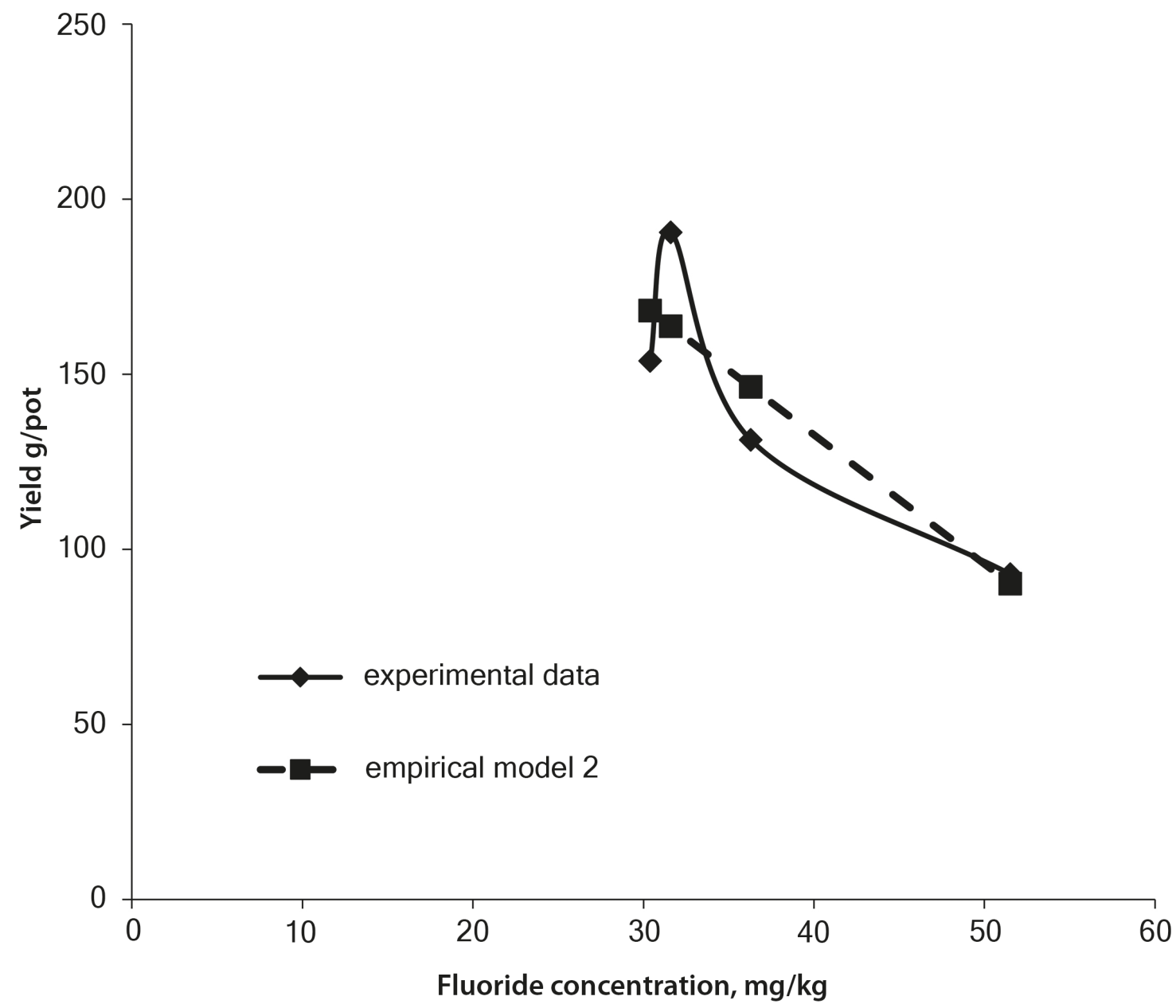

Fig. 4. The dependence of the yield of buckwheat on the concentration of fluoride in plant tissues (experiment with phosphorus fertilizers).

$\mathrm{kg}$ caused growth by $0.2 \mathrm{pH}$ units. The adverse effect of soil acidity on plants is largely determined by the phytotoxicity of aluminum. The transition of aluminum from the crystal lattice of clay minerals to the soil solution occurs at soil $\mathrm{pH}<5$ (Zheng 2010). Fluorine is able to bind $\mathrm{Al}$ ions in poorly soluble compounds, eliminating its negative effect on plants. In their research on soils contaminated with fluoride, Elrashidi et al. (1998) reported that F release from the soil occurs in the following order: alkaline soil $>$ acid soil $>$ neutral soil; at the same time, the magnitude of $\mathrm{pH}$ decreases in the following order: neutral soil $>$ acid soil $>$ alkaline soil. In their study, fluoride addition had a negative effect on the dry mass of barley grown on the acidic and neutral soil due to accumulation of toxic amounts of $\mathrm{F}$ in soil and due to increased mobility of Al.

In addition, application of fluoride regulates the ratio of ions in the soil to balance their concentrations, thus changing the nutritional conditions of agricultural crops, because sodium fluoride increases the mobility of macro- and microelements in soil (Bar-Yosef and Lindsay, 1986; Elrashidi and Lindsay, 1987; Szostek and Ciecko, 2017).

\section{Buckwheat yield depending on the increasing $\mathrm{N}$ fertilization (Experiment No. 1)}

There is scarce literature data reporting the effect of NK fertilizer on crop yield in soil contaminated with fluoride. We suppose that the negative effect of NK fertilizer on crop yield on fluoride-contaminated soil might be due to the excess release of $\mathrm{Al}$ ions into the soil solution, which together with toxic concentrations of fluoride and acid soil $(\mathrm{pH}=4.4)$ inhibited optimal growth of buckwheat. Elrashidi et al. (1998) reported that when F is added in acid soils naturally containing high amounts 
of $\mathrm{Al}$ and $\mathrm{Fe}$ hydroxides, $\mathrm{OH}^{-}$ions are released in relatively higher concentrations than from soils containing less amounts of these hydroxyl minerals. Mishra et al. (2014) found that at $\mathrm{pH}$ below 5.5, fluoride becomes more phytoavailable due to complexation with soluble aluminium fluoride. These complexes can be absorbed by plants or can increase the absorption potential of fluoride ion by plants. (Slavek et al., 1984; Stevens, 1996; Mishra et al., 2014) assumed that the precipitation of $\mathrm{F}$ as $\mathrm{AlF}_{3}$ at $\mathrm{pH}$ values less than 5 is the main retention process, since high concentrations of AlF3 are expected to remain in solution as a soluble complex (Farrah et al., 1987; Barrow and Ellis, 1986).

\section{Buckwheat yield depending on increasing P fertilization (Experiment No. 2)}

The highest productivity of the dry weight of buckwheat was achieved in the treatment fertilized with the maximum dose of phosphorus.

This effect could be explained by reactions between $\mathrm{P}$ and $\mathrm{F}$ and the formation of insoluble $\mathrm{F}$ minerals, which may be enhanced by the addition of $\mathrm{P}$ to the soils. Elrashidi et al. (1998) also found that the amount of F released decreases with the increase in $\mathrm{P}$ addition. Further, they found that $\mathrm{P}$ addition along with HF has an accumulative effect on $\mathrm{H}^{+}$concentration in these soils, thus suggesting the absence of any interaction between $\mathrm{P}$ and $\mathrm{F}$ in soils that may each enhance or inhibit one effect on the $\mathrm{pH}$.

Thus, the effect of nitrogen and phosphate fertilizers on buckwheat plants cultivated on highly acidic soddy-podzolic soil contaminated with fluoride differs significantly. Nitrogen fertilizer enhanced fluoride phytotoxicity, where the higher dose resulted in higher yield loss.

\section{Relationship between the concentration of fluoride in the tissues of buckwheat and its productivity}

The constructed models showed significant similarities in the trend of the changes in buckwheat yield with changes in fluoride concentration in the tissues: in the first experiment due to the use of nitrogen fertilizers; in the second experiment-with phosphorus fertilizer. In both experiments there was an average rate of decrease in the yield (y) with an increase in the fluoride concentration (x) by $1 \mathrm{mg}$ (3.69 and $4.1 \mathrm{~g} /$ pot, respectively, in the first and second experiments).

However, in the first experiment (nitrogen fertilizer), the empirical model better fitted the experimental data, and the quality of the empirical model was significantly higher than in the second experiment (phosphorous fertilizer), due to the different effect on the changes of yield. For example, in the treatment with $2 \mathrm{~g}$ of $\mathrm{P}_{2} \mathrm{O}_{5}$ the fluoride concentration in tissues was $30.4 \mathrm{mg} / \mathrm{kg}$, which corresponded to buckwheat yield of $153.8 \mathrm{~g} /$ pot. In the treatment with $3 \mathrm{~g}$ of $\mathrm{P}_{2} \mathrm{O}_{5}$, the fluoride concentration in tissues was $31.6 \mathrm{mg} / \mathrm{kg}$ and the yield was $190.5 \mathrm{~g} /$ pot. So, an approximately equal amount of fluoride in buckwheat tissues has a different effect on its productivity, indicating that the toxicity of fluoride depends on the conditions of the root nutrition of plants.-

Another finding is related to the use of orthophosphoric acid on acidic soddy-podzolic soil, which turned out to be more effective than the use of superphosphate. In the third treatments of both experiments, the yield of dry weight of buckwheat were $105.3 \mathrm{~g} /$ pot and $131.2 \mathrm{~g} /$ pot in the first and second experiments, respectively, with $30 \%$ difference. However, the concentration of fluoride in plant tissues differed little: 35.3 and $36.3 \mathrm{mg} /$ $\mathrm{kg}$ dry weight of plants, respectively. This also confirms the earlier conclusion that the same amount of fluoride in the tissues has a different effect on the productivity of buckwheat. The reasons for this are discussed later in the paper.

Determination of the effect of various forms of phosphate fertilizers on the phytotoxicity of fluoride requires special experiments and is not discussed in this paper.

An increase in the dose of nitrogen fertilizers in Experiment No. 1 did not cause antagonism between fluoride and nitrogen upon plant uptake. Moreover, the more fluoride was accumulated in buckwheat, the more nitrogen accumulated therein. The correlation coefficient indicates a strong positive relationship between these elements ( $\mathrm{r}=$ 0.86 ), indicating that when $\mathrm{F}$ and $\mathrm{N}$ are absorbed by the plants, synergy is manifested, i.e., enhanced uptake of one element increases the absorption of another. This possibly occurred due to increased solubility of organic matter in the soil contaminated with $\mathrm{NaF}$ (Polomski et al., 1982; Elrashidi and Lindsay, 1987). This is also confirmed by the findings of Szostek and Ciecko (2017), who showed that fluoride-contaminated soil caused an increase in the con-

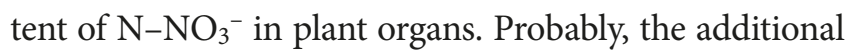
uptake of $\mathrm{N}$ by buckwheat in the conditions of fluoride contamination is associated with inhibition of the process of nitrogen assimilation, in which plants tend to compensate for the shortage in the amount of $\mathrm{N}$ that is involved in protein synthesis.

The negative effect of fluoride on protein synthesis by plants is known from earlier studies. Mitsko (1979) found that in fluoride-contaminated pea leaves the ratio of non-protein nitrogen to protein nitrogen in their tissues expands. Also, the negative effect of fluoride on plant amino acid metabolism was revealed (Gadi et al., 2012; Pal et al., 2012).

Obviously, deterioration of the nitrogen uptake process under increased fluoride assimilation by buck- 
wheat reduces the yield of plants; this is confirmed by the highly negative correlation between the concentration of fluoride in buckwheat and its productivity $(\mathrm{r}=-0.91)$.

On the contrary, the use of increasing doses of orthophosphoric acid in Experiment No. 2 contributed to the decrease of $\mathrm{F}$ uptake by buckwheat, leading to an increase in buckwheat productivity. Correlation analysis between the concentration of fluoride and phosphorus in the tissues of buckwheat indicated antagonism in the assimilation of these elements by plant roots $(r=-0.85)$. Obviously, phosphoric acid is able to compete with fluoride during plant uptake (Kabata-Pendias and Pendias, 1989).

On the other hand, the use of orthophosphoric acid is accompanied by dissolution of minerals, which results in increased concentration of elements in the soil solution (Al, Fe, Ca, Mg, etc.), capable of precipitating fluoride from poorly soluble compounds (Elrashidi et al., 1998; Sheudshen, 2003). The probability of this process increases with increasing dosage of orthophosphoric acid.

An important role in the process of detoxification of plant tissues from fluoride is assigned to alkaline earth metals capable of converting fluoride to low-active salts of $\mathrm{Ca}$ and $\mathrm{Mg}$. In Experiment No. 1, with increasing $\mathrm{F}$ concentration in buckwheat, an increase in Ca concentration was established with a highly positive correlation $(\mathrm{r}=0.91)$, thus supporting the hypothesis of a synergistic effect when these elements are absorbed by buckwheat. This important role of $\mathrm{Ca}$ in detoxication of plant tissues from $\mathrm{F}$ was observed in the third treatments of both experiments. Bar-Yosef and Lindsay (1986) found that mobility of elements ranked in the following order: (Al, $\mathrm{Fe}, \mathrm{Ca})>(\mathrm{Mg}, \mathrm{K}, \mathrm{Mn}, \mathrm{P})>(\mathrm{Cu}, \mathrm{Zn}, \mathrm{B}, \mathrm{Mo}, \mathrm{Ba})>(\mathrm{Cd}$, $\mathrm{Cr}, \mathrm{Ni}$ ), where an increase in the element mobility was far more pronounced at the highest $\mathrm{F}$ concentration. In our case, the difference in the absorption of Ca by buckwheat in the treatments of both experiments explains such a significant difference in its productivity, since the concentration of fluoride and phosphorus in plants was almost the same.

Most likely, the replacement of superphosphate with orthophosphoric acid contributed to the additional amounts of calcium in the soil solution due to the dissolution of soil minerals and better absorption of this element by plants. Moreover, higher Ca concentration in soil encouraged precipitation of $\mathrm{CaF}_{2}$, thus decreasing the availability of $\mathrm{F}$ to the plant (Morshina and Fanaskova, 1985; Pickering, 1985).

Our results showed that as phosphorus nutrition increases, the protective role of calcium weakens, while that of phosphorus increases. This is confirmed by the correlation coefficient between these elements indicating their antagonism during uptake of $\mathrm{Ca}$ and $\mathrm{P}$ by plants $(r=-0.97)$.
Mitsko (1979) showed that increasing the concentration of $\mathrm{Mg}$ in an incubation mixture of phosphoglucomutase from $5 \times 10^{-4} \mathrm{M}$ to $2 \times 10^{-3} \mathrm{M}$ did not reduce the inhibitory effect of fluoride but, contrarily, increased it. Perhaps this explains a twofold decrease in the concentration of $\mathrm{Mg}$ in the tissues of buckwheat in the dose range from 0 to $3 \mathrm{~g}$ of $\mathrm{N}$ per pot.

So, buckwheat plants under fluoride pollution conditions can both increase the supply of necessary elements that reduce the toxic effect of fluoride, and also can regulate the supply of the elements that enhance the harmful effects of the toxicant. In Experiment No. 1, this suggestion is supported by the strong negative correlation between $\mathrm{Mg}$ and $\mathrm{Ca}$ uptake by plants $(\mathrm{r}=-0.98)$.

Sheudshen (2003) showed that the inhibition of phosphoglucomutase by fluoride is seven times weaker when $\mathrm{Mn}$ acts as the activating metal instead of Mg. The correlation between these elements in the experiment with nitrogen fertilization indicates antagonism in the uptake by buckwheat $(\mathrm{r}=-0.91)$.

Obviously, an antagonism of $\mathrm{Mg}$ and $\mathrm{Mn}$ uptake by plants is not permanent. Probably, unbalanced nitrogen nutrition in fluoride-contaminated soil disturbs Mg uptake by buckwheat, which affects its productivity. The correlation coefficient indicates a strong negative relationship between assimilation of these elements by plants $(r=-0.94)$, while the correlation coefficient between $\mathrm{Mg}$ content in the plants of Experiment No. 1 and the yield showed strong positive correlation between them $(r=0.95)$, since this element is involved in the activation process of about 80 enzymes.

There is an opinion that excess $\mathrm{F}$ anions will bind $\mathrm{Mn}$ in the plant tissues, exerting an inhibitory effect on a number of enzymes. Litvinovich et al. (1998) established that there was an increase in the concentration of $\mathrm{Mn}$ in cotton leaves cultivated near an ammophos production factory under conditions of strong aerial pollution with fluoride.

It is likely that the enhancement of Mn intake by buckwheat is aimed at maintaining the necessary amount of its physiologically active compounds in functional cellular structures. The correlation coefficient between the content of $\mathrm{F}$ and $\mathrm{Mn}$ in buckwheat in the experiment with ammonium nitrate was $r=0.7$. This example also indicates the regulatory function of cation absorption by buckwheat plants under fluoride pollution.

Elrashidi et al. (1998) reported that $\mathrm{F}$ and $\mathrm{P}$ additions to soil and their interactions had a highly significant effect on Mn uptake by barley plants. In their study, contrary to our findings, increased $\mathrm{F}$ addition to the acid soil decreased the uptake of Mn by plants. However, similarly to our findings they also observed that increasing $\mathrm{P}$ additions significantly increased the Mn content of the plants at all levels of fluoride concentration. 
The dissolving effect of orthophosphoric acid on soil minerals resulted in an increase in the available potassium in the soil, which was actively assimilated by plants. We revealed significant differences in the content of this element in the plants grown with and without orthophosphoric acid. Such a high accumulation of potassium in buckwheat in Experiment No. 2 most likely was not related to the real needs of the plants, but was a consequence of replacing the lacking $\mathrm{Ca}$ and $\mathrm{Mg}$ cations to maintain acid-base balance in the buckwheat itself. This assumption is confirmed by the correlation coefficients between the concentration of $\mathrm{Ca}$ and $\mathrm{K}$ in plants of both experiments. In Experiment No. 1, r was -0.59, i.e., an increase in Ca uptake by plants was accompanied by a decrease in the concentration of $\mathrm{K}$, and in Experiment No. 2, $r$ was -0.98

However, an antagonism between $\mathrm{Ca}$ and $\mathrm{K}$ during plant uptake is not a permanent matter. Nebolsin and Nebolsina (2005) found that at very low potassium content in buckwheat plants, an increase in the amount of $\mathrm{Ca}$ and $\mathrm{Mg}$ in soil does not lead to a decrease in the potassium content in their tissues. At the same time, with average potassium content in buckwheat plants an antagonism was revealed between $\mathrm{K}, \mathrm{Ca}$ and $\mathrm{Mg}$ uptake. With an excessively high level of potassium nutrition, $\mathrm{Ca}$ and $\mathrm{Mg}$ were not able to restrict their assimilation in plants. Thus, with an increase in the level of supply of one element, the need for other elements, as a rule, changes.

The chlorine content in plants is usually high, and the rate of penetration of $\mathrm{Cl}$ into tissues is higher than that of $\mathrm{SO}_{4}^{-2}$ and $\mathrm{HPO}_{4}{ }^{-2}$ (Demolon, 1961). The increased fluoride concentration in buckwheat, which resulted in a significant decrease in the chlorine concentration in both experiments, indicates an antagonism in the assimilation of $\mathrm{F}$ and $\mathrm{Cl}$ by buckwheat plants.

The ability of buckwheat to activate metabolic processes, allowing regulation of flow of individual elements into the tissue, is due to the plant protective mechanisms that reduce the harmful effects of the toxicant. In some cases, this is aimed at maintaining the necessary amount of physiologically active compounds (enzymes) in plants, which are reduced as a result of inhibition of the activator metal by fluoride (for example, manganese). In others, the increased flow to the affected organs (for example, calcium) is directly related to the involvement of the latter in the detoxification of fluoride anions. In addition, anions, such as phosphorus, can compete with fluoride during assimilation by plant roots, preventing its accumulation in tissues.

The level of accumulation of $\mathrm{N}, \mathrm{Ca}, \mathrm{Mg}, \mathrm{K}, \mathrm{P}, \mathrm{S}$, $\mathrm{Mn}$ and $\mathrm{Cl}$ in the tissues of buckwheat cultivated under fluoride-contaminated soil is determined by complex processes of antagonism and synergism when they enter plant tissues. The essential role in this case is played by the ratio of the concentrations of elements in the soil.

\section{Conclusions}

Use of increasing doses of phosphate fertilizers contributed to an increase in the productivity of buckwheat while eliminating the harmful effects of fluoride; therefore, use of phosphoric fertilizers is recommended in the cultivation of crops on acidic fluoride-contaminated soils.

Excess of nitrogen in fluoride-contaminated soils led to a significant decrease in the productivity of buckwheat; therefore, the use of nitrogen fertilizers without the addition of phosphorus is ineffective.

Obtained results suggest that buckwheat is an ecologically plastic plant species, and the formation of its chemical composition is influenced by the complex processes of antagonism and synergism in the absorption of individual elements by plant roots.

Empirical models describing the dependence of the yield of buckwheat on the concentration of fluoride in the tissues in both experiments have significant similarities. The change in the concentration of toxicant in the tissues of buckwheat for $1 \mathrm{mg} / \mathrm{kg}$ dry weight of plants led to a decrease in productivity by approximately $4 \mathrm{~g} /$ pot.

\section{References}

Anshumali, B. K. 2014. Fluoride in agricultural soil: A review on its sources and toxicity to plants. Global Sustainability Transitions: Impacts and Innovations 3:29-37.

Barrow, N.J. and Ellis, A. S. 1986. Testing a mechanistic model. III. The effect of $\mathrm{pH}$ on fluoride retention by a soil. European Journal of Soil Science 37:287-293. https://doi. org/10.1111/j.1365-2389.1986.tb00030.x

Bar-Yosef, B. and Lindsay, W. L. 1986. Reactions, chemical equilibria and mobnility of fluorine in soils and uptake by plants. Bet Dagan, Izrael, United States-Israel Binational Agricultural Research Development Fund.

Bure, V. M. 2007. Methodology of statistical analysis of empirical data. St. Petersburg State University, 141 p. (In Russian)

Demolon, A. 1961. Growth and development of cultivated plants. Moscow, 44 p. (In Russian)

Elrashidi, M. A. and Lindsay, W. L. 1987. Effect of fluoride on $\mathrm{pH}$, organic matter and solubility of elements in soils. Environmental Pollution 47(2):123-133. https://doi. org/10.1016/0269-7491(87)90042-X

Elrashidi, M. A., Persaud, N., and Baliger, V. C. 1998. Effect of fluoride and phosphate on yield and mineral composition of barley grown on three soils. Communications in Soil Science and Plant Analysis 29(3/4):269-283. https:// doi.org/10.1080/00103629809369945

Farrah, H.S.J. and Pickering, W. F. 1987. Fluoride interations with hydrous alumin ium oxides and alumina. Australian Journal of Soil Research 25:55-69. https://doi. org/10.1071/SR9870055

Gadi, B. R., Verma, P., and Amra, R. 2012. Influence of NaF on seed germination, membrane stability and some biochemicals content in Vigna seedlings. Journal of Chemical, Biological and Physical Sciences 2(3):1371-1378. 
Gautam, R., Bhardwaj, N., and Saini, Y. 2010. Fluoride accumulation by vegetable and crops grown in Nawa Tehsil of Nagaur district (Rajasthan, India). Journal of Phytology 2(2):80-85.

Gupta, S. and Banerjee, S. 2011. Fluoride accumulation in crops and vegetables and dietary intake in a fluorideendemic area of West Bengal. Fluoride 44(3):153-157.

Hong, B. D., Joo, R. N., Lee, K. S., Lee, D. S., Rhie, J. H., Min, S. W., Song, S. G., and Chung, D. Y. 2016. Fluoride in soil and plant. Korean Journal of Agricultural Science 43(4):522536. https://doi.org/10.7744/kjoas.20160054

Ilkun, G. M. 1978. Pollution of atmosphere and plants. Kiev, Naukova Dumka. Doctoral thesis. (In Russian)

Kabata-Pendias, A. and Pendias, H. 1989. Trace elements in soils and plants. Moscow, Mir, 280 p. (In Russian)

Litvinovich, A. V., Osipov, A. I., and Pavlova, O. Yu. 1998. Influence of technogenic contamination on the chemical composition of the cotton plant. Agrochimia 1:71-77. (In Russian)

Mian, A. A., Haleema, B., Iqbal, M., Muhammad, N. A., Afia, Z., Ghulam, M., Ikram, U., and Imran, K. 2018. Fluoride toxicity and its effect on two varieties of Solanum lycopersicum. Research report. Fluoride 51(3):267-277.

Mishra, P.C., Sahu, S. K., Bhoi, A. K., and Mohapatra, S. C. 2014. Fluoride upate and net primary productivity of selected crops. Open Journal of Soil Science 4(11):388-398. https://doi.org/10.4236/ojss.2014.411039

Mitsko, V. N. 1979. Intake of fluoride in plants and its impact on growth, productivity and metabolism. Doctoral thesis, Kiev. (In Russian)

Morshina, T. N. and Fanaskova, T.P. 1987. Changes in soil properties caused by fluorine. Soviet Soil Science 19:74-79.

Nebolsni, A. N. and Nebolsina, Z. P. 2005. Theoretical basis of soil liming. St. Petersburg, 252 p. (In Russian)

Pal, C. K., Mondal, K. N., Bhaumik, R., Banerjee, A., and Datta, K. J. 2012. Incorporation of fluoride in vegetation and associated biochemical changes due to fluoride contam- ination in water and soil: a comparative field study. Annals of Environmental Science 6:123-139.

Pickering, W. F. 1985. The mobility of soluble fluoride on soils. Environmental Pollution Series B, Chemical and Physical 9:281-308. https://doi.org/10.1016/0143148X(85)90004-7

Polomski, J., Fluhler, H., and Blaser, P. 1982. Fluoride induced mobilization and leaching of organic matter, iron and aluminium. Journal of Environmental Quality 11:452-456. https://doi.org/10.2134/ jeq1982.00472425001100030027x

Sheudshen, A. Kh. 2003. Biochemistry. Maikop, 1024 p. (In Russian)

Singh, S. P., Tripathi, S. K., Kumar, V., and Raha, P. 2016. Monitoring of groundwater quality with respect to fluoride contamination around Hindalco industries Ltd. Renukut, Sonbhadra district, Uttar Pradesh, India. Nature Environment and Pollution Technology 15(2):579-582.

Slavek, J., Farrah, H., and Pickering, W. F. 1984. Interaction of clay with dilute fluoride solutions. Water, Air, and Soil PolIution 23:209-220. https://doi.org/10.1007/BF00206977

Stevens, D. Ph. 1996. Doctoral thesis The University of Adelaide, Waite Agricultural research Institute, Australia, 2996.

Szostek, R. and Ciecko, Z. 2017. Effect of soil contamination with fluoride on the yield and content of nitrogen forms in the biomass of crops. Environmental Science and Pollution Research 24(9):8588-8601. https://doi.org/10.1007/ s11356-017-8523-6

Vlasyuk, P. A. 1969. Biological elements in plant life. Kiev, Naukova Dumka, 350 p. (In Russian)

Weinstein, L. H. and Davison, A. 2004. Fluorides in the environment. UK, $287 \mathrm{p}$.

Zheng, Sh. J. 2010. Crop production on acidic soils: overcoming aluminium toxicity and phosphorus deficiency. Annals of Botany 106(1):183-184. https://doi.org/10.1093/ aob/mcq134 